\title{
How Indonesia media deal with Sustainable Development Goals
}

\author{
Irwansyah Irwansyah ${ }^{1, *}$ \\ ${ }^{1}$ Communication Department, Faculty of Social and Political Science, Universitas Indonesia, Jakarta
}

\begin{abstract}
After millennium development goals end it terms in 2015, members of United Nation agree to create new sustainable development goals (SDGs). The media are endorsed and needed to involve in the implementation of SDGs. Moreover, media in all its forms has a crucial role to play in the development agenda to ensure that citizens are well informed. The media has important roles to play, to inform, to educate, and to provide a platform for public debate and discussion. The media could serve as catalyst for citizens' empowerment and help to hold government and authorities to account. This study focuses on how media deal with its agenda setting in order to spread the information of SDGs to wider public. Based on theoretical assumption of the study, this study examines the media coverage of SDGs in 2017/2018; how SDGs has been understood and framed by media. By using a sequential mixed-method, this study applies quantitative approach to analyze all articles on SDGs. The qualitative approach is conducted to explore deeper insight of SDGs understanding from news management. This study found that not all SDGs are informed well. Only several SDGs are framed based on the concern of public policy.
\end{abstract}

\section{Introduction}

United Nations Educational, Scientific, and Cultural Organization (UNESCO) contribute sustainable development goals for communication and information. The SDG of UNESCO highlights the importance of freedom of expression, the safety of journalists, media development in both knowledge-driven and content-sensitive, promotion of universal access to information including open solutions and youth mobile initiative.[1] Therefore, the media are endorsed and needed to involve in the implementation of SDGs. [2] Moreover, media in all its forms has a crucial role to play in the development agenda to ensure that citizens are well informed. The media have a significant role to inform and educate, to provide a platform for public discussion, to serve as the catalyst for citizens' empowerment and to assist to hold authorities to account.

Previous studies show that specific topics about the environment such as climate change shapes the media agenda.[3],[4] Several media in different countries such as Australia, Germany, and India use print media to distribute the topics of climate change. [5]

\footnotetext{
* Corresponding author: irwansyah09@ui.ac.id
} 
Along with the ascendance of digital and online media, the agenda setting of print media is questioned [6]. Digital and online media may take a position of agenda setting from the print media. In this case, digital and online media set the agenda setting to influence print media and public policy.[7] The reversed position of agenda setting could lead the digital and online media into the priority source for public and policymakers.[8] The digital and online media could attenuate the agenda setting of print media.[9]

However, nowadays, most print media transform and expand their platform not only in print but also in digital, online, and mobile media.[10] These platforms lead to the new type of agenda setting. The converged media set a modified agenda based on the source from an official website, video sharing, blog or website, social media, social networking site, and others. The agenda of converged media could vibrant important issues to public and policymakers. At the same time, the agenda setting of converged media could set the agenda of social media, social networking sites, video sharing sites, blog, official website, and others.[6] Finally, the agenda setting both print media and digital and online media which called as converged media is still powerful to set the agenda of public and the policymakers. Therefore, this study focuses on how converged media deal with its agenda setting in order to spread the information of SDGs to the wider public.

\section{Method}

This study used mixed-methods to explain and to explore the finding. This study used Google news to crawl the articles from Indonesia online media. The result of crawling was filtered by two types of official media: (1) print media that have digital and online media; and (2) digital and online media that have not a print version. Indonesia media was defined as any media that established legally in Indonesia and they have published news in Bahasa Indonesia. This study excluded the other Indonesia media who serve in English or other languages since the media is targeted for specific readers.

After two categories of official media type, this study classified any news in English and Bahasa Indonesia keywords. The search of Google News features started with English key words such as "sustainable development goals (SDGs)", "sustainable development goals", and "SDGs". Then the crawl was continued by Bahasa Indonesia keywords such as "pembangunan berkelanjutan", dan "tujuan pembangunan berkelanjutan". However, Google News did not crawl all the news. In addition, this study used Google Search by adding several keywords such as "Kompas SDGs", "Media Indonesia SDGs", and "Republika SDGs". All of the news articles titles, the name of news media, published date, and news hyperlinks were managed via Ms-Excel. There were 90 news articles and opinions from August 29, 2016, to August 5, 2018.

This study used Nvivo to analyze the news articles. To collect news articles, NCapture embedded in Chrome was used. NCapture is the web browser extension that enables the researcher to quickly and easily capture content like web pages including digital and online news articles. NCapture is developed by QSR that enables the researcher to import the web material into NVivo.[11] After capturing the web-based online news, the 90 news articles and opinions were imported to the internal source of NVivo. $\square$

This study developed the definition of "deal with" as an agreement or an arrangement.[12] "Deal with" is also related to "share out". It refers to an action to do something in order to achieve something or in order to solve the problem. In terms of media, "how media deal with" means the media would publish information as (1) news based on fact and data, (2) opinions, or (3) advertising.[13] This study only focused on news articles published in Indonesia media. The main reason to exclude advertising is to the date of collection, there is no general and specific advertising about SDGs in observed media. 
The 90 observed news articles were coded into several categories. The first category is about the number news articles of Indonesia media. The Indonesia digital and online media were categorized into three indicators: (1) single digital and online platform media, (2) converged digital, online, and print media, and (3) other types of digital and online media that were not a part of previous indicators. This category would be presented as a percentage of the number of news articles.

The second category is about the chronological date of the published news article. This category made the arrangement of news articles in order of publication date from the first date of published news article after SDGs meeting on September 25-27, 2015 to the date of the current study on August 5, 2018. The arrangement would be completed with the name of media and the title of news articles. In addition, this category would be presented in the text content of the news. The third category is the number of news articles from the big three print newspapers that have digital and online media version. The category would be presented as the percentage of published news articles from each newspaper. Moreover, the category would be presented in the text of news content.

This study used "appropriateness" to validate tools, processes, and data.[14] Appropriateness would see from the desired outcome, methodology choice, methodology design, sampling and data analysis, and results and conclusions for the context of the study.

\section{Result and discussion}

This study found that Tribun News published more news articles about sustainable development goals (SDGs) topics (28.89\%) than other media. Tribun News is online media from regional news division of Kompas Group that provides various actual and fast news such as local news, national news, and international news. One of Tribun News regional division, Aceh.tribunnews.com (Serambinews.com) was the first digital and online media that published about SDGs on August 29, 2016. With the title "Transformasi Global (SDGs 2030)", the news articles informed about the end of millennium development goals (MDGs) and the bottom up process about sustainable development goals (SDGs) from 193 countries. The article informed the important of SDGs but at the same time, the article concerned about the international, national, and local problem in implementing the SDGs. Although the news of SDGs came from one of the region division of Tribun News, none of the news substance came from Aceh region. The 416 words or nine paragraphs were about the history of the end of MDGs, the process of SDGs meeting and agreement, the important and the objective of SDGs, the concern and the problem of SDGs, and the real situation of SDGs in global and Indonesia contexts.

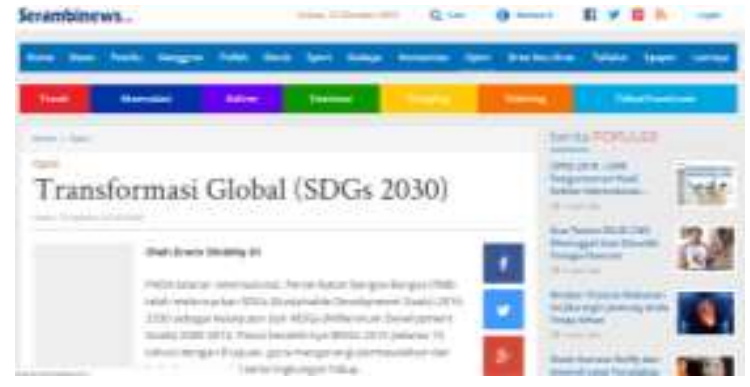

Fig. 1. First digital and online media that published about SDGs.

In term of publication date, Indonesia media both print, digital, and online media were late to post about SDGs. Based on data collection from Google news, Indonesia online media such as Tribun News took eight months to post or to inform about SDG as news 
articles. While Indonesia print magazine that has digital and online version such as Gatra took more time to inform about SDGs. Gatra posted news with titled "Bappenas: Implementasi Sustainable Development Goals Melalui Geopark" (Bappenas: Implementation of Sustainable Goals Through Geopark) on July 14, 2017. In term of Indonesia print media that has a digital and online version, Kompas posted on July 18, 2017.
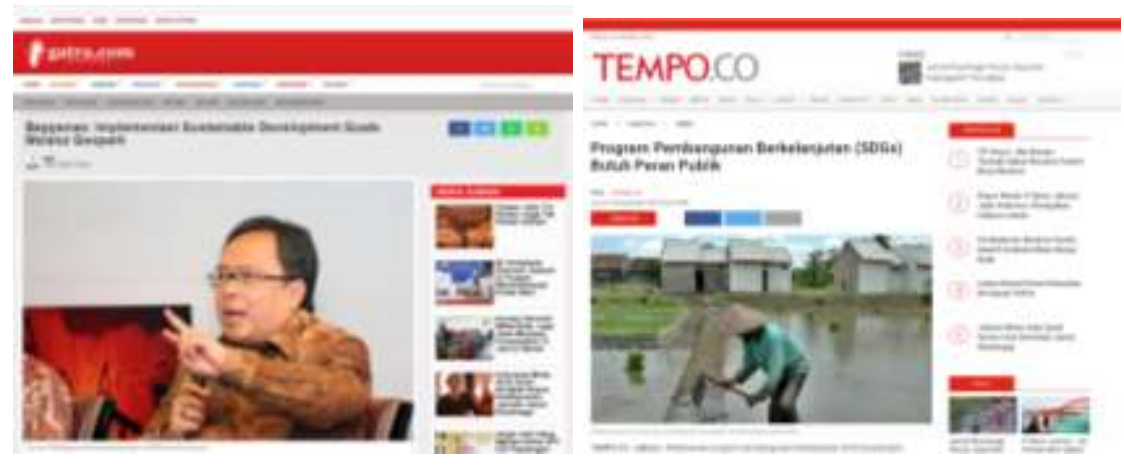

Fig. 2. Indonesia print media have a digital and online version that published about SDGs.

Interestingly, while this study traced longer to the date of the SDGs meeting on September 25-27, 2015. Tempo, an Indonesia print magazine that has a digital and online version, posted the news about SDGs earlier before the meeting (September 24, 2015). This news articles came from the press release sent by one of an international non-government organization that would attend the SDGs meeting. The more interesting, the release came from the discussion forum with the topic "Addressing Implementation Translating SDGs Into National Development Agenda," in Ford Foundation Building, New York on September 23, 2015. The release stated that the SDGs agenda would have a similar fate with MDGs agenda if it was not supported by public participation. Moreover, the result of the MDGs agenda was far from the target. The title of news article was "Program Pembangunan Berkelanjutan (SDGs) Butuh Peran Publik" (Sustainable Development Goals Needs Public Role) which informed the way of civil society coalitions to encourage Indonesia government for involving public participation on SDGs agenda toward 2030.

Furthermore, most of the news articles $(89 \%, n=90)$ had neutral statements from their titles. For example, Tribunsumsel.com posted news articles titled "Peringati Hari Perempuan Internasional, WCC Palembang Bahas Tentang SDGs (Celebrate International Women Day, WWC Palembang Discusses SDGs)". Tribunsumsel.com posted news articles on March 8, 2018, in order to celebrate International Women Day. The neutral statement was embedded in the news articles since there is no positive statement (optimistic, promote, or support statement) or a negative statement (pessimistic, suspicious, or skeptic statement).

This study found that Indonesia media was not informed well. There is a huge gap of date from the first published news article on September 24, 2015, to the result of crawling of search engine on August 29, 2016. While the media is not informed well, this could lead the citizens did not get enough information either.[15]

This study also identified that digital and online news of Indonesia media become the first and dominant to post a news article about SDGs activities. In the growth of the Internet, many news media develop the digital and online version. The digital and online media versions respond to the challenge to develop news in short of time and looking for wider context. [16]

In addition, the news articles from digital and online news media come from different regions in Indonesia. This shows that Indonesia media concerns the SDGs activities. Moreover, the digital and online news media posted the news articles based on the activities 
of SDGs took place in the regions. A study from Reuters Institute also showed that digital of the local and regional newspaper would define and navigate the opportunities by creating digital-first news and adapting to user needs.[17]

News media management also puts a priority to spread any news articles including about SDGs activities. Moreover, the management asks their journalist to gather more information to give their users more news.[17] News media management just concerns how the users could satisfy and loyal to their media. For them, SDGs objectives and activities are a part of any facts to grab attention from their users. Therefore, the media only deals with any information and issues that give more benefits to their ideology and markets.

\section{Conclusion}

This study concludes that Indonesia media are not well informed about SDGs. A huge gap between the first date of the published news article to the date of first searched on the current study show that SDGs are not interesting information to be a news. Moreover, the news articles are mostly about the events and press release.

The digital and online versions of Indonesia Media have dominantly informed the SDGs news. Moreover, the media are a subdomain of a specific media group that published regionally. As a result, any SDGs news in specific regions that could not be covered by media print, television, and radio can be distributed widely via digital and online version.

SDGs could be as the posted news articles while the media agree if they give a significant impact not only for the public but also for decision-makers in public policy. So, SDGs activities may become the agenda of media if the media could take benefit of any news that media posted. SDGs activities are only a part of information products and services provided by media. Media would consider more about SDGs activities if they make the media could play their role not only as a mediation but also as a mediatization.

This study initiates the way of Indonesia media produces the news articles on SDGs based on the texts that are already published. Therefore, this study recommends that further study should give more detail on the life cycle assessment (LCA) on digital and online news media, especially on SDGs activities.

\section{Acknowledgements}

This work was supported by PDUPT Dikti 2018.

\section{References}

1. UNESCO, Education for Sustainable Development, 2017. [Online]. Available: http://www.unesco.org/new/en/brasilia/education/education-for-sustainabledevelopment/

2. UNESCO, Media's Role in Sustainable Development Undeniable, 18 December 2017. [Online]. Available: http://www.unesco.org/new/en/harare/about-this-office/singleview/news/medias_role_in_sustainable_development_undeniable/

3. R. Barkemeyer, F. Figge, A. Hoepner, D. Holt, J.M. Kraak, P.-S. Yu, Pol. and Sp. C. 126 (2017).

4. Irwansyah, Pac. Sci. Rev. B: Hum. and Soc. Sci. 58-65 (2016)

5. M. S. Schafer, A. Ivanova and A. Schmidt, Int. Com. Gaz., 152-176 (2014)

6. B. Sayre, L. Bode, D. Shah, D. Wilcox and C. Shah, Poli. \& Int., 7-32 (2010)

7. J. Last, The Weekly St., 22-24 (2004)

8. M. Prabowo, Irwansyah, J. Kom. Ind., 5-15 (2016) 
9. M. J. Dutta-Bergma, J. of Bro. \& Elect. Med., 41-60 (2004)

10. G. Drula, Communicar: Med. Edu. Res. J., 131-140 (2015)

11. NVivo, http://help-ncapture.qsrinternational.com, 2018. [Online]. Available: http://helpncapture.qsrinternational.com/desktop/topics/install_ncapture_for_chrome.htm.

12. Cambridge.org, Definition of Deal, 2018. [Online]. Available: https://dictionary.cambridge.org/dictionary/english/deal

13. G. Beattie, R. Durante, B. Knight, A. Sen, Advertising Spending and Media Bias: Evidence from News Coverage of Car Safety Recalls, February 2017. [Online]. Available:

https://www.eui.eu/Documents/DepartmentsCentres/Economics/Seminarsevents/Duran te-paper.pdf.

14. L. Leung, Validity, J. of Fam. Med. and Pri. Car., 324-327 (2015)

15. J. Miller, The New News Media: Democratic Implications of Undergraduate Education and News Consumption Over Social and Traditional Media (Canada, 2013)

16. N. Newman, Mainstream Media and the Distribution of News in the Age of Social Discovery (Oxford, 2011)

17. J. Jenkins, R.K. Nielsen, The Digital Transition of Local News, 2018. [Online]. Available: http://www.digitalnewsreport.org/publications/2018/digital-transition-localnews/ 